\title{
Culture-Specific Forensic Accounting Conceptual Framework: A Skills Set Theoretical Analysis
}

\author{
Mohammed Shanikat ${ }^{1} \&$ Ashfaq Khan $^{2}$ \\ ${ }^{1}$ Department of Accounting, Al-Balqa Applied University, Al-Salt, Jordan \\ ${ }^{2}$ UNE Business School, University of New England, Armidale, NSW, Australia \\ Correspondence: Mohammed Shanikat, Department of Accounting, Al-Balqa Applied University, Al-Salt, P.O. \\ Box 19117, Jordan. Tel: 962-5349-1111. E-mail: mohammed_shanikat@bau.edu.jo
}

Received: May 2, 2013

doi:10.5539/ijbm.v8n15p112
Accepted: May 17, $2013 \quad$ Online Published: July 12, 2013

URL: http://dx.doi.org/10.5539/ijbm.v8n15p112

\begin{abstract}
Forensic accounting, given its peculiar investigative stance, requires a specific skills set on the part of the forensic accountant, that integrates accounting, auditing and investigative skills. The Jordanian Anti-Corruption Commission's (JACC) struggle to investigate Maward's, a Jordanian state-own company, suspected corruption has raised serious concerns regarding the weak state of forensic accounting in Jordan, and the need for its adaptation to suit the country's peculiar context, to successfully institutionalize at the wider societal level and benefit the state in its aim for ensuring efficient utilization of the scarce resources at its disposal. This study is an attempt to deduce a country-specific conceptual framework for forensic accounting, which can be replicated, with suitable adaptations, to other countries with similar cultural backgrounds, and put forth some theory-supported suggestions to help guide future research in the area.
\end{abstract}

Keywords: forensic accounting, conceptual framework, institutional theory, foucault

\section{Introduction}

The rise in the white collar crimes, where evidences are comparatively more obscure and difficult to detect (Gottschalk, 2011), has necessitated equipping of auditors with forensic skills, particularly over the recent years (DiGabriele, 2009a; Carnes \& Gierlasinski, 2001). In the aftermath of several accounting scandals such as Enron and WorldCom in the USA, HIH Insurance in Australia, Royal Ahold in the Netherlands, Parmalat in Italy, and Equitable Life Assurance Society in the UK (Kleinman \& Anandarajan, 2011), as well as the collapse of one of the "Big Five" auditing firms (Arthur Anderson), and the two episodes of financial crises that followed afterwards, awareness about white-collar frauds committed by employees through embezzlement of funds, ensuring personal financial and non-financial gains at a cost to the society, and fraudulent financial reporting, has increased over the past (McMullen \& Sanchez, 2010); Harris, 2012). Despite criminal prosecutions and formal punishments (see Carnes \& Gierlasinski, 2001), accounting as a professional has had legitimacy and trust shocks experienced as a result as well (see Carnegie \& Napier, 2010; Konishi, 2010). The accounting and auditing professions were particularly hit hard at the collapse of Enron (Kleinman \& Anandarajan, 2011). The promulgation of the Sarbanes-Oxley Act 2002 and later on the Public Company Accounting Oversight Board (PCAOS) and the Statement of Accounting Standards No. 99 has heightened this awareness even further and added to the auditors' and accountants' responsibilities to detect fraud within organizations (DiGabriele, 2009a). The magnitude of egregious white-collar crimes in the USA alone is to the tune of US $\$ 300$ billion per annum, which points to the significance of the enhancement of the overall capacity of today's forensic accountants to effectively tackle the problem (see DiGabriele, 2009b).

A thorough disquisition of the past corporate scandals and the immense responsibility the discipline shoulders discerns that forensic accountant needs to possess peculiar skills and expertise for the effective discharge of their duties and the accomplishment of their onerous work objectives. In practice, successful forensic accountants collect and analyze evidence and report their findings as to whether a person's conduct merits the country's legal system's involvement. The National Institute of Justice (2007) asserts that forensic accountants' success in terms of objective evaluation of clients' work for authenticity and correctness is primarily dependent upon their expertise in accounting and skills in investigation and litigation. Therefore, demand for forensic accountants with required expertise has surged over the past decade or so, to deal with a variety of cases and industries. 
Academic institutions and stakeholder organizations that provide education in these fields are faced with a number of questions regarding the nature, extent, and format of a worthwhile curriculum that could address all pertinent issues facing the discipline (National Institute of Justice, 2007). Though the literature covers a variety of aspects of the issue, it does not fully address the requirements for improving the sector's efficacy both in terms of the accomplishment of its objectives in performing as per society's expectations and institutionalization of the discipline at the deeper societal level, and this conceptual paper aims to fill this void in the current literature. It goes beyond and evaluates the issues the discipline is facing in the light of some established theoretical constructs to help it pinpoint its shortcomings and reach optimal growth, both quantitatively and qualitatively, in Jordan's peculiar contexts.

Jordan is not immune to corruption; many suspected corruption cases have been referred to the State Security Court (SSC). Among those is the case of the National Resources Investment and Development Corporation, which is called 'Maward'. It is a financially and administratively independent state-owned corporation leading Jordan's drive towards urban regeneration and inner city development. It is Jordan's largest real estate developer, with a commitment towards generating considerable investment opportunities for the private sector, creating job opportunities, and stimulating economic growth. Maward, a Jordanian state-owned company, is under investigation for corruption by the Jordanian Anti-Corruption Commission (JACC). The JACC's president's comments that the case file consists of 40,000 pages, written in the English language, hint towards the intricate nature of the case on one hand and the lack of expertise to effectively tackle and handle the case, with objective outcomes for the government, on the other. A Jordanian journalist comment's further highlights the need for dexterous and shrewd forensic accountants: "...the president is in a critical need for experts gaining distinct skills more than translation from English to Arabic, reading through the lines and manipulating the accounting numbers into facts..." (Jebara, 2011). The journalist has, in fact, impliedly pointed towards the country's dire need for forensic accounts with skills-set that is best suited to the country's peculiar needs and requirements.

A country-specific forensic accounting conceptual framework, that would stipulate the skills set a forensic accountant should possess to effectively handle fraudulent and suspicious cases, both in the public and private sector, is what the society is expecting the government to deduce. This conceptual-cum-analytical paper aims to deduce such a conceptual framework for country that would be replicable to other Middle Eastern nations with similar circumstances. We expect this framework to provide a foundation for the development of forensic accounting standards, that would drive the business schools' curricula development initiative, thereby helping to overcome the country's dire need for effective forensic accountants to ensure efficient utilization of the country's scarce resources, and also help develop the country's private sector, for best societal outcomes. Another important contribution of this study is help the forensic accounting discipline better understand societal expectations of it and therefore adapt and reorient to effectively institutionalize itself as a legitimate entity at the wider societal level. The study, in accomplishing this, resorts to Foucault's (1980) notions of 'governmentality' and 'power' and DiMaggio and Powell's (1983) institutional theory.

The remainder of the paper is divided into four main sections: The first section reviews the relevant literature and sheds light on the significance of the issue, followed by a section on the theoretical framework to help readers view the issue with the lenses of the aforementioned theoretical underpinnings. The third section develops a 'framework' for the discipline's development and efficient functioning in the peculiar context of Jordan. The last section draws conclusions and proposes research areas to be considered by researchers.

\section{Literature Review}

Given the tedious and intricate nature of assignments, today's forensic accountants are entrusted, business schools around the world constantly evaluate their curricula and introduce new and/or revised forensic accounting courses (see DiGabriele, 2008; Carnes \& Gierlasinski, 2001). Traditional accounting graduates work as accountants and internal and external auditors in business organizations, and are expected to have a greater understanding of fraudulent business transactions and deals and forensic accounting. This adds to the business schools' responsibilities to develop their curricula accordingly. The surge in corruption cases in recent times coupled with highly risky nature of today's business has necessitated stern response and preparedness, in terms of the development of human and other resources, around the world, on the part of different stakeholders. McMullen and Sanchez (2010) in their survey concluded that the demand for forensic accountants would increase well into the foreseeable future, particularly in the area of fraudulent financial reporting. The need for forensic accountants both in the public and private sector is expected to continue to grow (Harris, 2012).

While several financial market players contributed to the early-and then the late 2000s financial crises, the crises primarily stem from the USA and then penetrated into different economies around the globe. The 2011 Financial 
Crisis Enquiry Commission's report, indirectly but clearly, signalled the shortcomings in the business schools' curriculum particularly in terms of lack of complete dexterousness imparted to and inculcation of ethical and professional values into the very personalities of the business graduates. Sheer neglect of regulations and standards and "systematic breakdown in accountability and ethics" were evident in the reckless, unprofessional, and unethical decisions of the business schools' 'working graduates', the report added. From the sustainability perspective, these graduates' business decisions, in several occasions such as the infamous 1984 Bhopal disaster, the OK Tedi Mine contamination of Fly River, the Chernobyl nuclear reactor accident with disastrous long-term ramifications for Western Europe and Russia, and many more, have contributed to the environmental degradation that has been affecting us all [see Wallace, 2010; Currie, Knights \& Starkey, 2010; Datar, Garvin \& Cullen, 2011 for detailed analyses of business schools' position in the post-financial crises era debate]. Currie et al. (2010, p. S1) have referred to the shortcomings in the business schools' imparting of sound professional knowledge and expertise to their graduates as "a fundamental intellectual failure". Costs of the recent financial crises to the world economy has been estimated at a staggering US\$500 billion (Greenlaw et al., 2008); these estimates were escalated to an alarming US\$1400 billion later in 2008 (Barrell \& Davis, 2008). Non-performing loans in the Asian countries have soared to about 30 percent of banks' total assets. In quarter of the cases of these financial crises, the cost to different European countries soar to around 10 percent of their Gross National Product (Llewellyn, 2002, p. 153); the situation necessitates analysis of the situation at a deeper level for root causes.

The unethical and reckless business decisions on the part of large corporations' executives, including the audit firms whose very job is to watch their clients and keep them on the right track, leading to the demise of these business giants, with consequences for the world economy, deduction of an effective conceptual framework, duly acceptable to the society as a legitimate recipient of the scarce resources at its disposal, and its meticulous compliance has (should) become the priority of all professional bodies, governments, and business schools. Building forensic accountants' 'capacity' to deal with the technical nature of today's fraudulent business transactions and decisions has gained high momentum since the early- and then the late-2000s financial crises. The accounting professional bodies place high emphasis on imparting comprehensive training to forensic accountants. Resultantly, most business schools, around the world, have adapted their curriculum to include forensic accounting as an additional course to effectively tackle the ethics-specific challenges today's business confronts, thereby increasing the number of risk-fraud-audit specific courses from two to three (Carpenter, Durtschi, \& Gaynor, 2011). Comparing this situation to Jordan, only two private-sector universities throughout the country offer degrees in accounting with a forensic accounting component. Policy-makers in the government and relevant professional bodies need to fill this gap.

Business schools in Jordan ought to revisit their curricula and redevelop them in the light of today's requirements. Effective auditing entails effective forensic accounting. Forensic accounting techniques, if employed effectively, will ensure high quality audit outcomes (DiGabriele, 2011; DiGabriele, 2009b). We argue these skills ought to reflect country or culture-specific peculiarities. As Cortese (2003, p. 16) put it.

$[\ldots]$ it is the people coming out of the world's best colleges and universities that are leading us down the current unhealthy, inequitable, and unsustainable path...

While formal punishments and criminal prosecution has always been in play and has become more intense following the financial crises (Carnes \& Gierlasinski, 2001), we argue it has not been thoroughly effective in preventing frauds. In the aftermath of the recent financial crises, society is now exerting pressure on professional audit firms to assume responsibility for detecting risk of fraud as well when conducting audit (Carnes \& Gierlasinski, 2001) - an expectation that requires the services of forensic accountants. Given the demand today's vexing business scenarios and fraudulent activities place on a typical forensic accountant's skill-set, the framework, we propose in the peculiar context of Jordan, emphasize dexterously crafted integration between all branches of accounting, including financial accounting, management accounting, auditing, fraud examination, and social sciences field of human psychology. Additionally, we consider the involvement of some of the shrewd auditors already working in the field with a good track record and business schools as crucial. With this paper a first step in this direction, we argue for the adaptation and reorientation of the current forensic accounting general standards, with an input from the above fields, to suit Jordan's peculiar forensic accounting current and future needs. We aim to put forth the proposed framework to be used as a reference point for other countries with similar circumstances, particularly the Middle East, for the development and adaptation of their own standards, in the light of the highly risky nature of today's business enterprises and the perplexing ways in which frauds are committed. Kleinman and Anandarajan (2008, p. 46) assert:

[...] In forensic accounting and auditing courses, students should be made aware not only of the 
accounting/tracing aspects of auditing and forensic accounting, but also of the environment in which fraud takes place and how it is enabled by events in one's surroundings. The presentation of inattentional blindness is not prevalent in forensic accounting and auditing courses.

Thus, the 'environment' and the 'surroundings' of a fraudulent activity matters and every country's business schools need to take this into account when developing their curricula (Kleinman \& Anandarajan, 2008).

Forensic accounting is an aspect of accounting application that deals with the mechanism used to record and summarize business and financial transactions according to legal issues (Ansari, 2005). Thornhill (1995) asserts that there is no standard definition for forensic accounting that could capture all aspects of its constitution of existence. Thornhill (1995) defines forensics as an accounting analysis to assist in legal matters. It is frequently associated with the analytical investigation of civil or criminal actions, such as white-collar crime, insurance casualty claims, loss measurements, accounting malpractices, and general abuse of trust relationships. Okoye and Akenbor (2009) see forensic accounting as a profession that applies financial skills to provide solutions to issues under investigation. It is a discipline with peculiar characteristics, that applies "....accounting and auditing skills to legal problems both civil and criminal...", where professionals command a variety of skills, as individuals or teams, such as expertise in various branches of accounting, knowledge of fraud, understanding of the nature of businesses/phenomena under investigation and applicable legal system (Okoye \& Akenbor, 2009, p.2).

What is peculiar to forensic accounting and different to most other disciplines is that it integrates accounting, auditing and investigative skills. Forensic accounting consists of two major components: (1) Litigation services that recognize the role of the public accountant as an expert or consultant and (2) investigative services that make use of the public accountant's skills, which may help in the court as testimony (DiGabriele, 2009a; NIJ, 2007). Forensic accounting may involve the application of special skills in accounting, auditing, finance, quantitative methods, certain areas of the law and research, and investigative skills to collect, analyze, and evaluate evidential matter and to interpret and communicate findings. Forensic accounting may involve either an attest or consulting engagement. Litigation support basically focuses on a notion that forensic accountants work as expert witnesses. It deals with issues related to the quantification of economic damages. A typical litigation support assignment would be calculating the economic loss resulting from a breach of contract (see Okoye \& Akenbor, 2009; NIJ, 2007; Hao, 2010).

Investigative accounting is often associated with investigations of criminal events. A typical investigative accounting assignment would be an investigation of employee theft (Crumbley et al., 2007). The forensic accountants therefore need a broader skill set beyond just fraud detection and auditing competence (McMullen \& Sanchez, 2010). Many researchers pointed to several important skills that should be perceived by the forensic accountants. These skills are basic accounting skills (McMullen \& Sanchez, 2010), written and verbal communication skills, analytical skills, interviewing skills (Crumbley et al., 2007) and personality traits (Wells, 2003). In addition, they need basic and computer forensics skills as almost every fraud involves the use of computers and electronic documents (Smith, 2005), data mining skills which use mathematical algorithms to seek hidden patterns in data (Crumbley et al., 2007). Forensic accountants may be engaged in public practice or employed by insurance companies, banks, police forces, government agencies and other organizations which are in need of the forensic accountants' services (Okoye \& Jugu, 2010). Forensic accountants are often involved in investigating and analyzing financial evidence, developing computerized applications to assist in the analysis and presentation of financial evidence, communicating their findings in the form of reports, exhibits and collections of documents, and assisting in legal proceedings, including testifying in court as an expert witness and preparing visual aids to support trial evidence (Okoye \& Jugu, 2010). Like auditing, forensic accounting involves collecting and interpreting the evidence and providing an opinion expressing what the evidence means (Huber, 2011). In order to properly perform these services, forensic accountants must have good knowledge in legal concepts and procedures and be able to identify substance over form when dealing with an issue (see Okoye \& Jugu, 2010; McMullen \& Sanchez, 2010; Crumbley et al., 2007).

In order to accomplish this holistic role, forensic accountants ought to possess characteristics, which would enable them to discharge their responsibility effectively. Ansari (2005) pointed to the characteristics that forensic accountant should have: curiosity, persistence, creativity, discretion, organization, confidence, and sound professional judgment. In addition to these, "people" skills, "puzzle" skills, flexibility and ability to work well in a team are also important characteristics (McMullen \& Sanchez, 2010). Forensic accountants must consider all the alternatives, and obtain and closely examine all the details about the events under investigation as well as the whole situation. In addition, a forensic accountant should be able to communicate clearly and concisely by writing a professional report. In particular, given the discipline's wide scope of operation, the lack 
of appropriate training, or the low quality of the business education curriculum, will beset the value of forensic accounting. Latest evidence highlights the significance of 'proper' training for a practicing forensic accountant. Carpenter et al. (2011), in their longitudinal empirical study, found that the delivery of a proper course in forensic accounting made a significant improvement, duly sustained over a period of time, to the subjects' level of scepticism when confronted with a high risk or fraudulent area of a typical business operational area.

\section{Theoretical Framework for the Study}

Forensic accounting requires a thorough understanding of accounting, the clients' business model operations. The discipline will flourish, legitimize, and institutionalise at the wider societal level, with optimal benefits for all stakeholders, only when it possesses, in terms of Foucault's (1980) theoretical constructs, the 'power' (of expertise and knowledge) and 'governmentality', which in turn stems from the power of knowledge and authority. Foucault (1980, p. 93) claims:

[...] power never ceases its interrogation, its inquisition, its registration of truth: it institutionalises, professionalises and rewards its pursuit.

Once a routine of socially and professionally acceptable curricula gets established, the practice will then spread across the country to all business schools, as predicted under the institutional theory's (DiMaggio and Powell, 1983) stance of 'isomorphism' (see Scott, 1995). Businesses sharing the same industry try to adopt practices prevalent in the industry and try not to stand or be deemed isolated (see Covaleski and Dirsmith, 1988; DiMaggio and Powell, 1983; Meyer and Rowan, 1977), though the speed of adoption of certain new social practices may vary among organizations (see Campanale, Cinquini, and Tenucci, 2010; Erakovic and Wilson, 2005; Burns and Scapens, 2000).

Although these 'authorities' are vested with the 'power' of knowledge and authority, i.e. 'governmentality' in Foucault's conceptualizations, they are 'accountable' and 'answerable' to the society for their responsibilities the concept of "control of control" as Power (1994, p. 300) describes. Thus, policy-makers in the relevant governmental departments, professional bodies, and practitioners, including business schools, ought to work in collaboration for effectively addressing the discipline's ex ante (education in all areas the proposed framework indicates, training, exposure to past experiences) and ex post (the incumbents' on the job training, continuous professional development, transparency and accountability) reasons of failure, to protect societal interests and ensure accomplishment of its inherent objectives.

\section{Conceptual Framework Deduced from the Study's Theoretical Framework}

As stated early, the main goal of this study is to build a tentative conceptual framework for forensic accounting for consideration by policy-makers in relevant government agencies, professional bodies, and business schools. It is expected to benefit several entities in both the public- and private sector, such as researchers, police, anti-corruption commissions, accountants, business enterprises, business schools in their curriculum development initiatives. A sound conceptual framework that accommodates all aspects of the discipline, in the specific contexts of a country, from the perspective of its efficacy in the efficient discharge of its responsibilities given challenges it is facing in today's business organizations is the necessity of today. Ethnical diversity, with a variety of needs and requirements, necessitates objective review and analysis of social practices and services (see Warnock-Parkes, Young \& Gudjonsson, 2010). In the case of China, for instance, Hao (2010) has indicated several country-specific requirements for the development of the forensic accounting discipline. Konishi (2010) also endorsed cultural influence on accountants' behaviours in conducting a business.

The proposed conceptual framework borrows from the relevant literature and the applicable established theoretical constructs on the development, legitimization, and eventual institutionalization of certain social practices. The framework establishes the base to align and coordinate the discipline-specific objectives, concepts and actions that underline forensic accounting. It aims to provide guidance on identifying and appreciating the circumstances the discipline finds itself in today and a reference point for the development of forensic accountants capable of effectively addressing and tackling the challenges the sector is facing today. Country-and culture-specific circumstances need to be considered when implementing forensic accounting and auditing-specific regulations (see Kleinman \& Anandarajan, 2008). In Jordan, there are only a limited number of accounting programs offering forensic accounting courses. Two Jordanian universities among 26 are teaching accounting discipline and offering forensic accounting related courses. Both these universities operate in the private sector - Applied Science Private University and American University of Madaba, and offer two elective courses related to forensic accounting. It is thus evident that there is a large void between the supply and demand for forensic accounting services. The country's education system ought to act in this connection, and this paper is an attempt in this direction to provide a 'framework' to guide any such attempts on the part of the 
government and the tertiary education sector.

Given Jordan's current state of business education curriculum, in most universities, as elaborated on above, we assert that business schools and relevant government agencies ought to pursue appropriate changes to the curriculum to enhance the capacity of their graduates to deal with the complex nature of today's businesses to effectively tackle fraud-related challenges. Theoretical and analytical exposure to past business frauds, coupled with practical training of potential forensic accountants, under the surveillance of a professional audit firm, where they have an opportunity to fully immerse into fraud-related situations and interact with practicing accountants (see Carpenter et al., 2011; Carnes \& Gierlasinski, 2001) must be made mandatory as part and parcel of their graduation requirements.

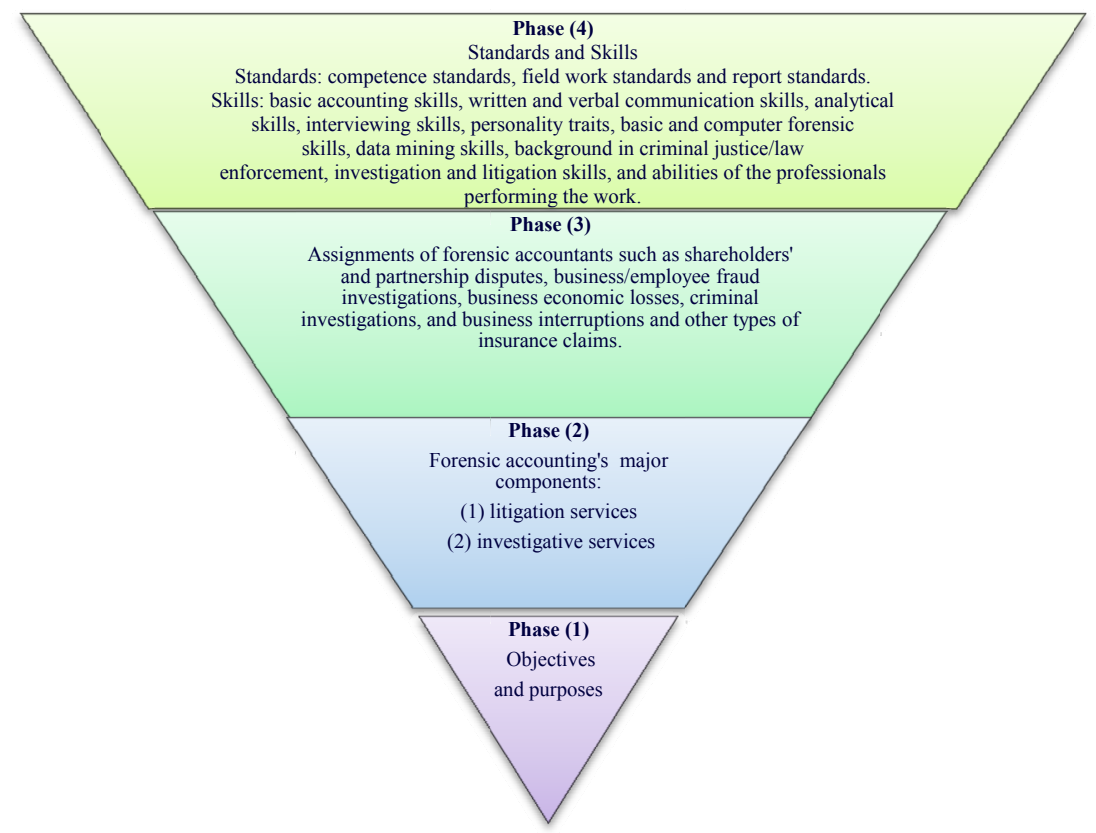

Figure 1. The conceptual framework of forensic accounting

As shown in figure 1, the conceptual framework is intended to provide a platform for the discipline's advancement in terms of effectiveness and efficiency. The framework encompasses the discipline from four perspectives: objectives, major components, duties and responsibilities, and skills and capabilities.

Under the framework, in addition to focus on skills directly relevant to the discipline-course contents, relevance, depth, international focus, etc., business schools ought to emphasize skills that indirectly relate to the discipline's functioning in the Jordan's peculiar contexts-problem solving, analytical, critical, deductive, investigative, oral and written communication (see DiGabriele, 2008), English language proficiency to effectively deal with multinational corporations operating in the country, and group work skills. As rarely a person individually possesses all the skills required by the discipline, forensic accountants often need to work collaboratively in a group, and therefore group skills come into play to ensure optimal outcome for all stakeholders. DiGabriele's empirical study revealed that the discipline's focus needs to be holistic rather than narrow to effectively discharge its entrusted responsibilities in today's complex business world and intricate fraudulent situations.

A brief elaboration on each of the four perspectives from the stand point of the discipline's changed set of responsibilities to cope with its changed set of operational circumstances would suffice for the purpose of the paper. This will also help the reader understand the significance of the proposed changes the discipline must embrace to ensure its effective and efficient functioning to placate the societal expectations of it, and eventually its legitimate existence and long-term survival. We posit that the discipline's objectives need to be carefully deduced and clearly stated, considering the country's short- and long-term aspirations, which will guide its work assignments under the two broad spheres of 'litigation' and 'investigation' services, which in turn will highlight 
the set of skills forensic accountants must possess in order to discharge their duties effectively and efficiently. While crafting each phase of the proposed framework, we maintain, as Kleinman and Anandarajan (2008) argue, country-and culture- specific circumstances must be duly adhered to. Close coordination between business schools and practicing accountants is crucial for today's forensic accounting graduates so business schools do not lose touch with the practical world around them (Carnes \& Gierlasinski, 2001). The discipline will have the power of 'governmentality' and 'knowledge' to help institutionalise itself at the wider societal level in the country, only if it is equipped with dexterous professionals who possess all the skills set needed for the effective discharge of their professional commitments, both collectively and severally.

\subsection{Objectives and Major Components}

The objectives and components of the proposed forensic accounting framework are many fold and chase one another, and therefore are presented together. In order for the discipline to command the 'power' of authority and knowledge and 'governmentality' to legitimize its doctrine as binding and effective, the discipline must align the set of objectives it aims to accomplish with the demands society is placing on it given the threats and risks it is facing in the business world today.

Table 1. Major components of forensic accounting

\begin{tabular}{|c|c|}
\hline Investigative Accounting & Litigation Support \\
\hline $\begin{array}{l}\text { - Reviewing a business scenario and provision of } \\
\text { suggestions regarding possible courses of action. } \\
\text { Assisting with the protection and recovery of } \\
\text { embezzled assets through civil action or criminal } \\
\text { prosecution. } \\
\text { - Coordinating with other experts, including: Private } \\
\text { investigators, Forensic document examiners, } \\
\text { Consulting engineers }\end{array}$ & $\begin{array}{l}\text { - } \\
\text { - } \quad \text { Refsisting in obtaining documentation necessary to support or } \\
\text { - } \\
\text { assessment of the case and identify areas of concern. } \\
\text { Evaluating financial evidence, and relevant issues for } \\
\text { strengths and weaknesses of the position taken. } \\
\text { - } \\
\text { Assisting with settlement discussions and negotiations. } \\
\text { Attending the trial to hear the testimony of the opposing } \\
\text { expert and providing assistance with cross-examination. }\end{array}$ \\
\hline
\end{tabular}

Source: Adapted from Okoye and Akenbor (2009, p 4) and Zysman (2011).

Table 1 shows a summary of the major roles forensic accounting boasts to discharge. As shown in table 1, forensic accountants are looking beyond numbers, providing testimonies in courts and handling civil and criminal cases. Their duties today encompass a wide variety of skills and capabilities. In a nutshell, they aim to help the society (government and public sector) ensure efficient and effective utilization of the scarce resources at its command. Forensic accountants can be of assistance in various ways, including investigative accounting and litigation support.

\subsection{Responsibilities Entrusted}

Giving the readers an account of the duties and responsibilities forensic accountants are entrusted during the usual course of their work will also provide a background for the proposed conceptual framework the paper aims to put forth for consideration by the policy-makers. Foucault (1980) argues that the power of knowledge and authority and the notion of 'governmentality' are interconnected and the interplay between these theoretical constructs helps institutionalize a social practice at a deeper level. Forensic accountants in the Jordan's context currently possess the power of 'authority' and 'governmentality' but lack the power of 'knowledge' and 'skills' at a level that is crucial for the discipline's institutionalization power. Societal expectations of forensic accountants to effectively and efficiently discharge these obligations will ensure the discipline's deeper institutionalization in the society and the achievement of a legitimate status in the sight of the general public. Therefore, through the proposed conceptual framework, we endeavour to incorporate a representative set of skills that business schools and governments must arrange to inculcate into prospective forensic accountants to enable them to discharge all these assignments effectively and efficiently to the satisfaction of all stakeholders, including the society. This will qualify the sector for the grant of legitimate status by the society, which will endorse the sector for a due share in the resources the society is in possession of.

As discussed above, the literature on accountability also imposes obligations on the government and business schools to ensure inculcation of necessary skills and expertise in prospective forensic accountants so that they become capable of discharging their duties effectively to the satisfaction of what is expected of them by the society and governments. Also, the literature on human resource management advocates that always people 
should be entrusted responsibilities as per their skills and trainings. Thus, before holding forensic accountants responsible for their actions, entities vested with the 'power' of authority-'governmentality' and 'knowledge', i.e. the government, business schools, and professional bodies, must ensure imparting all training and skills to prospective forensic accountants that are essential for them to effectively discharge their responsibilities.

Table 2. Examples of assignments for forensic accountants

\begin{tabular}{|c|c|}
\hline $\begin{array}{l}\text { Entrusted responsibility } \\
\text { classification }\end{array}$ & Description \\
\hline Criminal investigations & $\begin{array}{l}\text { Forensic investigations often relate to criminal investigations on behalf of the police. Forensic accountants' } \\
\text { reports are prepared with the objective of presenting evidence in a professional and concise manner. }\end{array}$ \\
\hline $\begin{array}{l}\text { Shareholders' and } \\
\text { partnerships disputes }\end{array}$ & These assignments often involve a detailed analysis of accounting records to quantify the issues in dispute. \\
\hline $\begin{array}{lr}\text { Personal } & \text { Injury } \\
\text { Claims/Motor } & \text { Vehicle } \\
\text { Accidents } & \end{array}$ & $\begin{array}{l}\text { Forensic accountants are often asked to quantify the economic losses resulting from a motor vehicle accident. } \\
\text { Forensic accountants need to be familiar with the legislation in place which pertains to motor vehicle accidents. }\end{array}$ \\
\hline Other Types of Insurance & $\begin{array}{l}\text { Insurance policies differ significantly as to their terms and conditions. Accordingly, these assignments involve a } \\
\text { detailed review of policies to investigate coverage issues and the appropriate method of calculating the loss. }\end{array}$ \\
\hline Claims & $\begin{array}{l}\text { Forensic accountants are often asked to assist from either an insured or insurer's perspective in the settlement of } \\
\text { a case. }\end{array}$ \\
\hline $\begin{array}{l}\text { Business/Employee } \\
\text { Fraud Investigations }\end{array}$ & $\begin{array}{l}\text { Business investigations can involve funds tracing, asset identification and recovery, forensic intelligence } \\
\text { gathering and due diligence reviews. Employee fraud investigations often involve procedures to determine the } \\
\text { existence, nature and extent of fraud and may concern the identification of a perpetrator. These investigations } \\
\text { often entail interviews of personnel who had access to the funds and a detailed review of the documentary } \\
\text { evidence. }\end{array}$ \\
\hline $\begin{array}{l}\text { Business } \\
\text { Losses }\end{array}$ & $\begin{array}{l}\text { Examples of assignments involving business economic losses include contract disputes, construction claims, } \\
\text { product liability claims, trademark and patent infringements, and losses stemming from a breach of a } \\
\text { non-competition agreement. }\end{array}$ \\
\hline & $\begin{array}{l}\text { These investigations are often approached from two different but complimentary perspectives, these being: } \\
\text { - } \quad \text { Technical - determining if a breach of Generally Accepted Accounting Principles or Generally }\end{array}$ \\
\hline Professional Negligence & $\begin{array}{l}\text { Accepted Auditing Standards or other standards of practice has occurred; and } \\
\text { - } \\
\text { If the professional in question is an accountant then forensic accountants could be involved with both } \\
\text { perspectives. If the matter involves some other profession, forensic accountants will normally be retained to } \\
\text { perform only loss quantification. }\end{array}$ \\
\hline $\begin{array}{l}\text { Mediation } \\
\text { Arbitration }\end{array}$ & $\begin{array}{l}\text { Because of their familiarity and comfort with legal issues and procedures some forensic accountants have } \\
\text { equipped themselves with special training and become involved in alternative dispute resolution (ADR). ADR } \\
\text { services include both mediation and arbitration and are designed to help individuals and businesses resolve } \\
\text { disputes with minimal disruption and in a timely fashion. }\end{array}$ \\
\hline
\end{tabular}

Source: Adapted from Zysman (2011).

Table 2 presents the various types of assignments forensic accountants often become involved in. As shown in table 2, Forensic accountants may be required to discharge several types of responsibilities and become involved in a wide range of investigations across a wide range of industries (Ansari, 2005).

\subsection{Standards and Skills}

In general, all forensic accounting assignments include the following steps: meeting the client, performing a conflict of interest check, performing an initial investigation, developing an action plan, investigating and obtaining the relevant evidence, performing the analyses, and finally reporting and communicating their findings to their employers. It is crucial to note that before this 'assignment completion cycle' completes, a typical forensic accountant would have, ideally, resorted to a wide range of skills and expertise to derive his/her conclusions. Thus, it can be logically deduced that only the possession of right skills would ensure objective outcomes of his/her analyses with potential benefits to all stakeholders, or the carrying out of the assignment would, intelligibly, deteriorate the quality of the process, for all stakeholders. The examples of assignments forensic accountants are usually expected to complete while at job, thus, necessitate acquisition of corresponding training and skills. The conceptual framework this study aims to forward to entities vested with 
authority for consideration while developing policies for the sector, encompasses a comprehensive skills set a forensic accountant needs to be equipped with, either collectively as member of a team or severally, to tackle issues that confront them while at work, as described in section 4.2 above. This conceptual paper argues for a set of standards to govern the discipline and its incumbents and guide it for optimal societal benefit. These standards could be divided into three major categories: competence standards, field work standards and report standards, which all revolve around the educational, professional and personal skills that forensic accountants should possess in order to be successful in their forensic accounting assignments, and call upon public and private sector business schools and other training schools to upgrade their curricula accordingly.

The notion of accountability, as described above, adds the imparting of these skills to potential forensic accountants to the sphere of responsibilities of the government as well as the business schools and training houses, both in the public and private sectors. These skills are basic accounting skills, written and verbal communication skills, analytical skills, interviewing skills, personality traits, basic and computer forensics skills, data mining skills, background in criminal justice/law enforcement, investigative and litigations kills, and human skills. Field work standards revolve around the techniques that should be followed by forensic accountants in order to perform the assignments in a professional manner [for a detailed account of the specific skills set today's forensic accountant is expected to possess, see DiGabriele, 2008, 2009b]. Understandably, the skills set needs to be adapted in the context of some countries with peculiar context.

Table 3. Proposed standards for forensic accountants

\begin{tabular}{|c|c|}
\hline $\begin{array}{l}\text { Competence } \\
\text { Requirements }\end{array}$ & Skills sets \\
\hline $\begin{array}{l}\text { 1. Educational, } \\
\text { professional and personal } \\
\text { skills }\end{array}$ & $\begin{array}{l}\text { Basic accounting skills in both financial and management accounting areas, written and verbal communication } \\
\text { skills, analytical skills, interviewing skills, personality traits, computer forensics skills, data mining skills, } \\
\text { background in criminal justice/law enforcement, investigative and litigation skills, human psychology, and } \\
\text { team/group skills. }\end{array}$ \\
\hline \multicolumn{2}{|l|}{$\begin{array}{l}\text { 2. } \quad \text { Field Work } \\
\text { Requirements }\end{array}$} \\
\hline $\begin{array}{l}\text { - Step 1: Meeting } \\
\text { the client }\end{array}$ & $\begin{array}{l}\text { Meeting with the client to obtain an understanding of important facts, players and issues at hand, is the crucial } \\
\text { first step and needs to be handled very dexterously. Interpersonal, communication, human, interviewing, and } \\
\text { investigative skills are required for the effectiveness of this step in terms of objective outcomes for each party } \\
\text { involved. }\end{array}$ \\
\hline $\begin{array}{l}\text { Step 2: Performing } \\
\text { a conflict of interest } \\
\text { check }\end{array}$ & $\begin{array}{l}\text { A conflict of interest check is of utmost significance for ensuring objective outcomes for all stakeholders, and } \\
\text { should be carried out as soon as the relevant parties are established. }\end{array}$ \\
\hline $\begin{array}{l}\text { - Step 3: Performing } \\
\text { an initial investigation }\end{array}$ & $\begin{array}{l}\text { It is often useful to carry out a preliminary investigation prior to the development of a detailed plan of } \\
\text { action. This will allow subsequent planning to be based upon a more complete understanding of the issues. } \\
\text { Technical expertise in the area under investigation and all branches of accounting, including computer forensic } \\
\text { skills, and knowledge of the policies and procedures of the business model under investigation are crucial for } \\
\text { the effectiveness of this step. }\end{array}$ \\
\hline $\begin{array}{l}\text { - Step 4: Developing } \\
\text { an action plan }\end{array}$ & $\begin{array}{l}\text { Action plan will take into account the knowledge gained in steps } 1 \text { to } 3 \text { and set out the objectives to be achieved } \\
\text { and the methodology to be utilized to accomplish them. }\end{array}$ \\
\hline $\begin{array}{l}\text { - Step 5: Obtaining } \\
\text { the relevant evidences }\end{array}$ & $\begin{array}{l}\text { Depending on the nature of the case this may involve locating documents, economic information, assets, a } \\
\text { person or company, another expert or proof of the occurrence of an event. }\end{array}$ \\
\hline $\begin{array}{l}-\quad \text { Step 6: Performing } \\
\text { the analysis }\end{array}$ & $\begin{array}{l}\text { The actual analysis performed will be dependent upon the nature of the assignment and may involve: } \\
\text { calculating economic damages, summarizing a large number of transactions, performing a trace of the assets, } \\
\text { performing present value calculations utilizing appropriate discount rates, performing a regression or sensitivity } \\
\text { analysis, utilizing a computerized application such as a spread sheet, data base or computer model, and utilizing } \\
\text { charts and graphics to explain the analysis. }\end{array}$ \\
\hline \multirow{2}{*}{\multicolumn{2}{|c|}{$\begin{array}{l}\text { 3. Reporting } \\
\text { Requirements }\end{array}$}} \\
\hline & \\
\hline $\begin{array}{l}\text { - Step 7: Preparing } \\
\text { the report }\end{array}$ & $\begin{array}{l}\text { Often a report will be prepared which may include sections on the nature of the assignment, scope of the } \\
\text { investigation, approach utilized, limitations of scope and findings and/or opinions. The report will include } \\
\text { schedules and graphics necessary to properly support and explain the findings. }\end{array}$ \\
\hline
\end{tabular}

Source: Adapted from McMullen and Sanchez (2010, p 42) \& Zysman (2011). 
Table 3 demonstrates the educational and skills standards expected of forensic accountants to possess to be able to effectively discharge their responsibilities, both to their employers and the society at large. As shown in table 3 the framework is divided into four succinct phases, and is a coherent system of concepts that flows from a set of objectives that identifies the purpose of forensic accounting. The set of carefully deduced objectives, duly informed by the literature and the theoretical constructs employed, enlighten the remaining, operational components of the framework. For forensic accountants, in order to be effective, must have knowledge and expertise in a wide variety of area, including human psychology, knowledge of local customs, values, culture, and business model. Business schools' curriculum needs to be re-visited and adapted to reflect this. Only if the discipline will have the 'power' of knowledge and expertise, dully recognized and appreciated by the society, will it deeply institutionalise itself with utmost benefit to the country.

\section{Conclusion}

The significance of the forensic accounting branch of auditing for the effective and efficient utilization of a country's resources cannot be over-emphasized, and substantial amount of literature addresses the area from several angles. This conceptual paper takes the discussion further and analyses the issue from the theoretical perspectives of Foucult's (1980) 'power' and 'governmentality' and DiMaggio and Powell's (1983) institutional theory. We argue that the discipline is in dire need for a sustained capacity development of its incumbents, through appropriate training and development initiatives (see Carpenter et al., 2011), to effective address the intricate challenges confronting today's businesses. We argue that the discipline, in the peculiar context of Jordan, as well as in general, must adapt, both theoretically and practically, taking both ex ante (education in all areas the proposed framework indicates, training, exposure to past experiences) and ex post (the incumbents' on the job training, continuous professional development, transparency and accountability) measures. This will help it fully institutionalize at the wider societal level, sustain and survive in the long run, and be accepted as a legitimate member of the society with benefits flowing to the community in ensuring efficient utilization of its scarce available resources. The paper, borrowing from established theoretical frameworks on the construction, development, and eventual institutionalization of social practices, focused on the need for evolution of the discipline in the peculiar context of Jordan. It aimed to develop a conceptual framework to inform the government on appropriate policies on the development and implementation of the discipline to the country's full advantage. In a nutshell, the study aimed to examine forensic accounting skills requirements and to develop conceptual model guidelines to be referred to by policy makers and business schools in the country. In addition to assisting public- and private-sector institutions, the conceptual framework presented is intended to aid professional trainers working in this area, including business schools, in tailoring their training curricula to suit today's forensic accounting needs and requirements. This study portrayed forensic accounting as a new area in the context of Jordan and presented a case, through developing conceptual model guidelines, for its effective development and institutionalization at the wider societal level, with a capacity to ensure effective discharge of responsibility to both the government and the society.

The significance of building potential forensic accountants' capacity through proper training and education (Carpenter et al., 2011) is highly reflected in the development of the conceptual model, which is expected to benefit the discipline from several angles - education, practical training, and capacity development - a novel initiative that contributes to and fills the current void in the literature (see also Kleinman \& Anandarajan, 2011). The framework apprises all stakeholders on the flaws present in their respective contributions to the discipline's development. In addition to assisting institutions, which are in need for forensic accountant services, the conceptual framework presented is intended to aid professional trainers working in this area. Further, practicing professionals who seek opportunities to acquire new skills in the area of forensic accounting may also benefit from this conceptual framework. In particular, the framework aims to inform business schools on their curriculum development, which will address the issue at the grass root level in the country's peculiar contexts.

The framework needs to be considered for implementation, after a thorough analysis through empirical studies, by the government, professional bodies, and business schools - all entities vested with the 'power' of authority and knowledge, which are, in terms of Foucault's (1980) theoretical conceptualizations of 'power' and 'governmentality' and the interplay between the two, essential for the institutionalization of the social practice at the societal level. The model then, as an institutionalized social practice, is expected to spread across the country, as predicted by the 'isomorphism' and 'coercive' pillars of the institutional theory (DiMaggio \& Powell, 1983; see also Scott, 1995).

\section{References}

Ansari, K. M. (2005). Corruption and Forensic Accounting. Ohio CPA Journal, July-September. 
Barrell, R., \& Davis, E. P. (2008). The Evolution of Financial Crisis of 2007/8. National Institute Economic Review: SAGE.

Burns, J., \& Scapens, R. W. (2000. Conceptualizing Management Accounting Change: An Institutional Framework. Management Accounting Research, 11, 3-25. http://dx.doi.org/10.1006/mare.1999.0119

Campanale, C., Cinquini, L., \& Tenucci, A. (2010). Do Management Accounting Systems Influence Organizational Change or Vice-Versa? Evidence from a Case of Constructive Research in the Healthcare Sector. Social Science Research Network, Online Document. Retrieved May 2012, from http://ssrn.com/abstract=1656943 http://dx.doi.org/10.2139/ssrn.1656943

Carnegie, G. D., \& Napier, C. J. (2010). Traditional accountants and business professionals: Portraying the accounting profession after Enron. Accounting, Organizations and Society, 35, 360-376. http://dx.doi.org/10.1016/j.aos.2009.09.002

Carnes, K. C., \& Gierlasinski, N. J. (2001). Forensic Accounting Skills: Will Supply Finally Catch Up to Demand? Managerial Auditing Journal, 16(6), 378-382. http://dx.doi.org/10.1108/02686900110395514

Carpenter, T. D., Durtschi, C., \& Gaynor, L. M. (2011). The Incremental Benefits of Forensic Accounting Course on Skepticism and Fraud-Related Judgments. Issues in Accounting Education, 26(1), 1-21. http://dx.doi.org/10.2308/iace.2011.26.1.1

Cortese, A. (2003). The Critical Role of Higher Education in Creating a Sustainable Future. Planning for Higher Education, 31(3), 15-22.

Covaleski, M. A., \& Dirsmith, M. W. (1988). An Institutional Perspective on the Rise, Social Transformation, and Fall of a University Budget Category. Administrative Science Quarterly, 33, 562-587. http://dx.doi.org/10.2308/iace.2011.26.1.1

Crumbley, D. L., Smith, G. S., \& Apostolou, N. G. (2007). A Broad Approach to Forensic Accounting is Needed. The Value Examiner, March/April, 13-19.

DiGabriele, J. A. (2008). An Empirical Investigation of the Relevant Skills of Forensic Accountants. Journal of Education for Business, 83(6), 331-338. http://dx.doi.org/10.3200/JOEB.83.6.331-338

DiGabriele, J. A. (2009a). Implications of Regulatory Prescriptions and Audit Standards on the Evolution of Forensic Accounting in the Audit Process. Journal of Applied Accounting Research, 10(2), 109-121.

DiGabriele, J. A. (2009b). Forensic Accountant: A Closer Look at the Skills Forensic Accounting Education Should Emphasize. The Forensic Examiner, Summer, http://dx.doi.org/10.1108/09675420910984673

DiGabriele, J. A. (2011). Revisiting the Integration of Forensic Accounting and the Auditing Paradigm. The Forensic Examiner, Summer, 70-73.

DiMaggio, P. J., \& Powell, W. W. (1983). The Iron Cage Revisited: Institutional Isomorphism and Collective Rationality in Organizational Fields. American Sociological Review, 48, 147-160. http://dx.doi.org/10.2307/2095101

Erakovic, L., \& Wilson, M. (2005). Conditions of Radical Transformation in State-Owned Enterprises. British Journal of Management, 16, 293-313. http://dx.doi.org/10.1111/j.1467-8551.2005.00467.x

Foucault, M. (1980). Two Lectures. In C. Gordon (Ed.), Power/Knowledge: Selected Interviews and Other Writings 1972-1977. The Harvester Press Limited, Brighton, Sussex.

Gottschalk, P. (2011). Prevention of White-Collar Crime: The Role of Accounting. Journal of Forensic and Investigative Accounting, 3(1), 23-48.

Gray, R., Owen, D., \& Adams, C. (1996). Accounting \& Accountability. Prentice Hall: London.

Greenlaw, D., Hatzius, L., Kashap, A., \& Shin, H. S. (2008). Leveraged Losses: Lessons From the Mortgage Market Meltdown. US Monetary Policy Forum.

Hao, X. (2010). Analysis of the Necessity to Develop the Forensic Accounting in China. International Journal of Business and Management, 5(5), 185-187.

Harris. T. (2012). Forensic Accountants Are Increasingly Becoming Part of the Legal Team. Journal of Forensic \& Investigative Accounting, 4(1), 369-370.

Huber. W. D. (2011). Does The American Accounting Association Exist? An Example of Public Document 
Research. Journal of Forensic \& Investigative Accounting, 3(2), Special, 1-67.

Jebara, J. (2011). Call to the prime minister of Jordan: The anti-corruption Commission is in critical need for help. Saraya News (Electronic). Retrived November 2011, from http://www.sarayanews.com/object-article/view/id/54381

Kleinman, G., \& Anandarajan, A. (2011). Inattentional Blindness and its Relevance to Teaching Forensic Accounting and Auditing. Journal of Accounting Education, 29, 37-49. http://dx.doi.org/10.1016/j.jaccedu.2011.08.002

Konishi, T. (2010). Fraud by Certified Public Accountants in Japan and the United States. Asian Criminology, 5, 99-107. http://dx.doi.org/10.1007/s11417-010-9089-0

Llewellyn, D. (2002). An Analysis of the Causes of Recent Banking Crises. European Journal of Finance, 8, 152-175. http://dx.doi.org/10.1080/13518470110071182

McMullen, D. A., \& Sanchez, M. H. (2010). A Preliminary Investigation of the Necessary Skills, Education Requirements, and Training Requirements for Forensic. Journal of Forensic \& Investigative Accounting, 2(2), 30-48.

Meyer, J. W., \& Rowan, B. (1977). Institutionalized Organizations: Formal Structure as Myth and Ceremony. American Journal of Sociology, 1, 340-363. http://dx.doi.org/10.1086/226550

National Institute of Justice. (2007). Education and Training in Fraud and Forensic Accounting: A Guide for Educational Institutions, Stakeholder Organizations, Faculty, and Students. Special Report. Retrived April 2012, from https://www.ncjrs.gov/pdffiles1/nij/grants/217589.pdf

Okoye, E. I., \& Akenbor, C. O. (2009). Forensic accounting in developing economies-problem and prospects. The University Advanced Research Journal, 1, 1-13.

Okoye, E. I., \& Jugu, Y. G. (2010). An empirical investigation of the relevant skills of forensic accountants in Nigeria. Journal of Knowledge Management, 1(2), 34-47.

Power, M. (1994). The audit society. In A. G. Hopwood \& P. Miller (Eds.), Accounting as Social and Institutional Practice. Cambridge: Cambridge University Press.

Roberts, J., \& Scapens, R. W. (1985). Accounting systems and systems of accountability-understanding accounting practices in their organisational contexts. Accounting, Organizations and Society, 10(4), 443-456. http://dx.doi.org/10.1016/0361-3682(85)90005-4

Schatzki, T. R. (2002). The Site of the Social: A Philosophical Account of the Constitution of Social Life and Change. Pennsylvania State University Press: University Park, PA.

Scott, W. R. (1995). Institutions and Organizations. Sage Publications: Thousand Oaks, USA.

Sinclair, A. (1995). The chameleon of accountability: Forms and discourses. Accounting, Organizations and Society, 20(2-3), 219-237. http://dx.doi.org/10.1016/0361-3682(93)E0003-Y

Smith, G. S. (2005). Computer Forensics: Helping to Achieve the Auditor's Fraud Mission? Journal of Forensic Accounting, 6(1), 119-134.

Thornhill, W. T. (1995). Forensic Accounting- How to Investigate Financial Fraud. New York: Irwin Professional Publishing.

Warnock-Parkes, E., Young, S., \& Gudjonsson, G. (2010). Cultural sensitivity in forensic services: findings from an audit of South London forensic inpatient services. Journal of Forensic Psychiatry \& Psychology, 21(1), 156-166. http://dx.doi.org/10.1080/14789940903202179

Wells, J. (2003). The Fraud Examiners: Sleuthing Careers Bring CPAs Personal and Professional Satisfaction. Journal of Accountancy. Retrived July 2012, from http://www.journalofaccountancy.com/issues/2003/oct/thefraudexaminers.htm

Zysman, A. (2011). Forensic Accounting Deymystified. Retrived September 2011, from http://www.forensicaccounting.com/

\section{Copyrights}

Copyright for this article is retained by the author(s), with first publication rights granted to the journal.

This is an open-access article distributed under the terms and conditions of the Creative Commons Attribution license (http://creativecommons.org/licenses/by/3.0/). 